\title{
THE NATURAL ORGANIZATION OF BRAZILIAN INTER- AND SUBTROPICAL LANDSCAPES
}

\section{Aziz Nacib AB'SÁBER}

(Originally published in III Simpósio sobre o Cerrado, 1971, Editora Blücher and Editora da Universidade de São Paulo, as A organização natural das paisagens inter e subtropicais brasileiras. Translated by P. E. Vanzolini, revised by Thomas R. Fairchild.)

\section{INTRODUCTION}

Present conditions are rather favorable to the development of interdisciplinary studies of the organization of Brazilian inter- and subtropical landscapes. Among such conditions are the easy access to the diverse physiographical and ecological regions, the very large number of aerial photographs that are available, and a permissive attitude toward the formation of interdisciplinary teams. The theme in itself is attractive, as the display of Brazilian inter- and subtropical landscapes is markedly original within the tropical world.

Although most of the country is subject to the conflicting influences of Nature and Man, there still exist fairly favorable conditions for the characterization of natural spaces, in an objetive attempt to reconstruct their primary organization. It will perhaps be the task of the present generation of Brazilian researchers to document this issue in the literature on earth and life sciences in Brazil.

From the beginning I want to stress that it is by all means convenient to intensify studies on the functioning and organization of Brazilian landscapes, taking into account regional and local conjunctures resulting from anthropic actions. Undoubtedly the analysis of the interference of processes, predatory actions, and harmful aggressions - unconsciously brought about by man - is just as important for the application of scientific principles as the effort to understand the ecological conditions of less disturbed areas.

Prehistoric man in Brazil seems to have caused little disturbance to the inter- and subtropical landscapes. The unified evolution of the most diverse landscapes in Tropical America during the last 10,000 years included the aboriginals as one additional element in the global development of the landscapes. It was the contrary of what succeeded in Africa, where a Recent fauna of gigantic animals, and human groups over 500,000 years old caused telling changes in some landscapes. It seems to me that the development of Brazilian intertropical landscapes was on the whole more harmonious, better integrated and balanced than what happened on the other side of the Atlantic Ocean.

\section{THE GREAT BRAZILIAN LANDSCAPE DOMAINS}

Six great landscape and macroecological domains are at present recognized in Brazil. Four of them are intertropical, occupying over 7.5 million $\mathrm{km}^{2}$; the other two, subtropical, are noticeably smaller, adding up to a little more than 0.5 million $\mathrm{km}^{2}$.

The great domains, defined by vegetational and morphoclimatic features of great spatial extent and generality, include landscape patterns of sub-regional character and eventual enclaves of extraneous landscapes, recurrent vegetational features related primarily to other domains. On the other hand, peculiarities of compartmentation, sedimentary strata of paleoclimatic significance, and paleozoological and paleobotanical records show that, during the Quaternary, these domains did not always exhibit the features and distribution evident at the time of arrival of the first Europeans.

In sum, the domais are:

Domain of the forested Amazonian lowlands. A markedly zonal, equatorial to subequatorial area. First order extent of over 2.5 million $\mathrm{km}^{2}$. Labyrinthine (Rio Amazonas) or meandrous (main tributaries) floodplains, tabuleiros (Editor's note: low sedimentary plateaus, tablelands) with convex slopes, and low rounded hills with convex slopes (E.n.: halforange hills) on the margins of the Amazonian sedimentary basin; residual relief in the form of sugarloaves that may have been inselbergs more than once during the Quaternary; discrete Neogene pediplanation and pedimentation levels; terraces supported by gravel beds or lateritic crusts; blackwater rivers in autochthonous drainage areas, drainage thoroughly perennial.

Domain of the semi-arid inter-plateau 


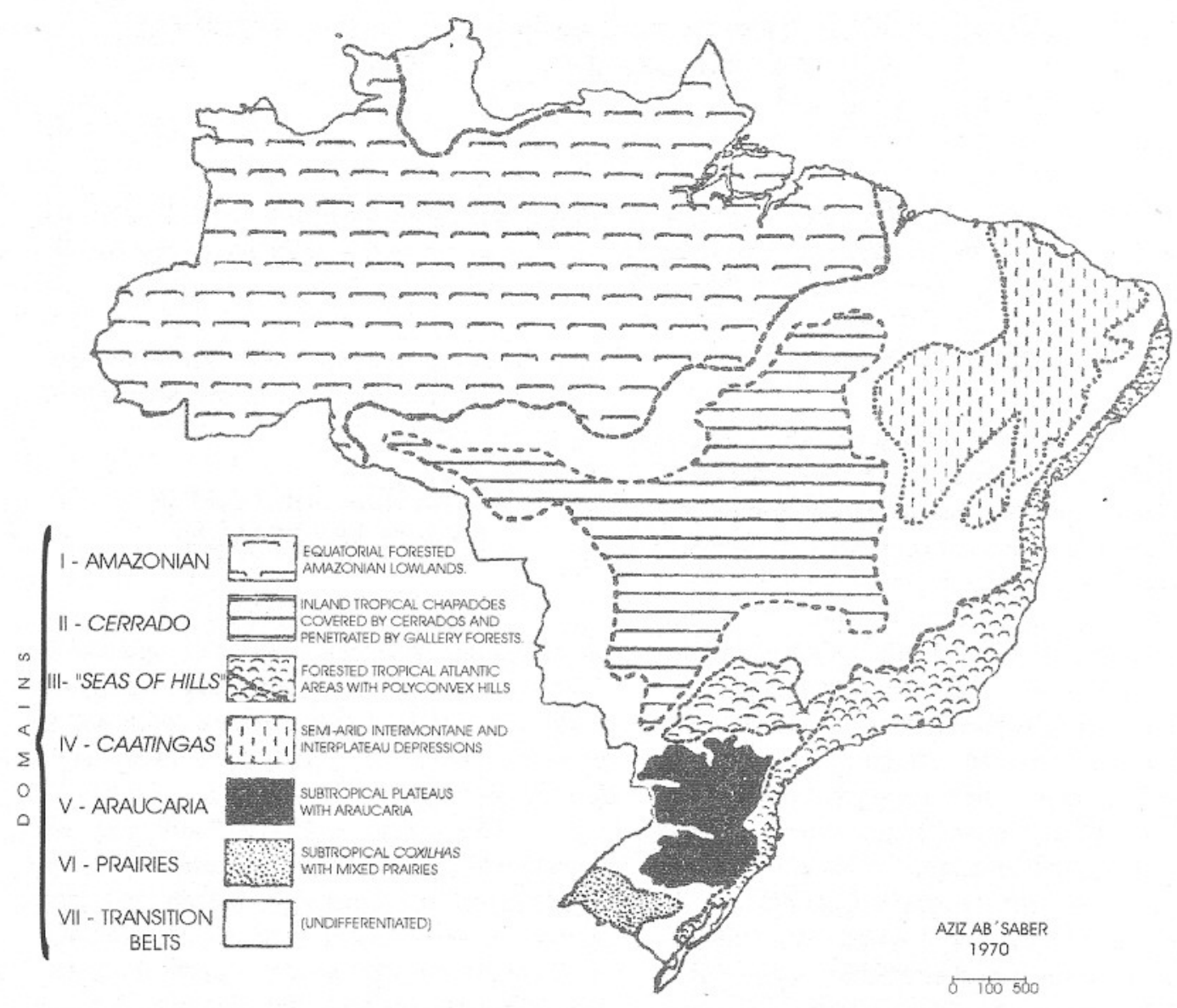

FIGURE 1 - Brazilian morfoclimatic domains (core areas)

depressions of the Northeast. Sub-equatorial and tropical. Azonal. Second order extent, $700-850,000 \mathrm{~km}^{2}$. Inter-plateau depressions reduced to veritable erosion plains, given the great extent of pediplanation and the thoroughness of the process; remains of Neogene pediplains ("superficies sertanejas") reduced in many places to present erosion plains by Quaternary resumption of pediplanation; eventual outcrops of fresh rock within areas of rock weathered to depths of 1-3 m; network of local stony floors; intermittent drainages, because of irregular and poorly distributed rainfall (350-600 mm/year, with strong year to year unevenness); semi-anastomosed channels with characteristic, unmistakable pattern; notable fields of crystalline inselbergs (Milagres, Patos, Quixadá).

Domain of the forested "seas of hills" ("mares de morros"). First order spatial extent, approximately 1 million $\mathrm{km}^{2}$. Azonal, extending along the Atlantic facade of Brazil. Extensive mamelonization (E.n.: neologism from the
Portuguese mamelonização, complex processes of slope rounding in crystaline terranes, polyconvex slope pattern) on all levels, masking planed summit or intermontane surfaces, levels of pedimentation or even terrace levels. Polyconvex slopes (LIBAULT, 1971), with maximum degree of mamelonization; weathering and mamelonization are more evident on intermontane levels, which leads to the supposition of an alternation of sedimentation and mamelonization; meandrous plains and predominance of fine sediments in alluvial channels; superimposed soils, which means colluvial deposits burying stone lines; remarkable sugarloaf fields; rainfall $1000-4500 \mathrm{~mm}$ /year; tropical forest originally covering $95 \%$ of the area. Enclaves of araucaria on high places, of cerrados in several low compartments of the inland plateaus, where forested chapadões predominate (seas of hills) (E.n.: chapadões are high plains with complex structure or table-like rolling plateaus). Domain of the "chapadões" covered by 
cerrados and penetrated by gallery forest. First order spatial extent, 1.8-2-million $\mathrm{km}^{2}$. Roughly zonal, like the savanna belts of Africa. Massive complex plateaus and compartmented sedimentary plateaus, cerrados and cerradões on the interfluves; continuous gallery forest, of varying width; headwaters in dales, i.e., small swampy amphitheatres; soils in general with low primary fertility; both primary and secondary elements of the drainage perennial, waterways on slopes and interfluves intermittent; very broad interfluves and widely or spaced valleys; little branching of the drainage in the core area; forest enclaves on better soils and around springs; no mamelonization; particular types of fluvial channels, generally nonmeandrous on the plateaus; levels of pediplanation on plateau compartments, step-like pediments and terraces with gravels; indications of climatic and landscape fluctuations in the central and peripheral intermontane depressions; climate of Sudanese type, rainfall 1300-1800 mm/year, concentrated in the summer, relatively low in winter. Forest enclaves (capões) of varying area.

Domain of the araucaria plateau. Approximately $400,000 \mathrm{~km}^{2}$ in area; subtropical humid climates with mild winters. Medium altitude plateaus, $800-1300 \mathrm{~m}$ high, covered with araucaria forests of diverse density, including mosaics of mixed prairies and small araucaria woods - in galleries, on hillslopes or around headwaters. Depth of weathering very variable, with imperfectly convex hills except in the gneissic area around the Curitiba basin. Eventual colluvia on slopes, covering subrecent topography, with large microrelief irregularities, corresponding to a drier climate (e.g. the plateau south of Lajes and north of Vacaria). The araucaria cover is denser on the basaltic plateaus of medium relief. Islands of grassland, mixed high prairies, in areas of occasional sandstone outcrops (Lajes, Ponta Grossa, Purunã Plateau). More than by its intrinsic relief, this domain is characterized by great pedological differences in comparison to the other Brazilian intertropical plateaus. Additionally, the "aging" of Atlantic polar air masses in the area lowers the temperature throughout this region (states of Paraná, Santa Catarina and northeastern Rio Grande do Sul). Drainage is perennial and rainfall rather evenly distributed throughout the year. The higher areas (Plateau of São Joaquim, Lajes, Curitibanos) are subject to eventual snowfalls.

Domain of the mixed prairies of southeastern Rio Grande do Sul. Approximate area
$80,000 \mathrm{~km}^{2}$, comprising a sort of border for the domain of the Pampas prairies while epitomizing a more or less individualized landscape pattern of the Uruguayan-Argentinian prairies. A landscape of temperate humid and sub-humid areas, subject to summer droughts, with a rather original landscape ensemble: it is a domain of pluriconvex hills, including grassland on gentle slopes and gallery forest along alluvial channels. The soils differ from everything that is known from tropical Atlantic Brazil, including patterns peculiar to the margins of the prairie domain. Drainage is perennial and predominantly meandrous, with small volume and low regional density. The domain occupies sedimentary terrains of diverse age, as well as basaltic areas, and makes inroads into crystalline areas of the Uruguay-Rio Grande do Sul plateau, commonly known as the "Serras de Sudeste".

\section{THE BELTS OF TRANSITION AND CONTACT BETWEEN THE GREAT BRAZILIAN LANDSCAPE DOMAINS}

From my travels along itineraries meaningful to the understanding of natural landscapes, I early understood that linear borders cannot be drawn between the great morphological and ecological domains. A preliminary attempt at charting the core areas demonstrated the existence of a complex network of transition and contact belts - in places narrow, in places broad and complex. From the outset, it was evident that hidden within the transition and contact corridors was a large number of combinations of heterogeneous physiographic facts. In reality, every sectorof these elongate belts represents a peculiar regional combination of ecological and physiographical events, that may occur again in neighboring areas yet which is almost never repeated at a distance. It was easy to suppose that between domains A and $B$ there would occur transitions or contacts of type $\mathrm{A}+\mathrm{B}$. It was noticed, however, that there are belts which occupy broad irregular bands between domains $\mathrm{A}, \mathrm{B}$ and $\mathrm{C}$, with a remarkable increase in the number of combinations through mosaic contacts, with local subtransitions. Field research in several key areas (especially Maranhão and Bahia) revealed that, besides areas of complex contact among three or more contiguous domains, there are vegetation buffers along certain segments of these so-called transitional belts. Thus nuclei of vegetation may appear without direct connection with $\mathrm{A}, \mathrm{B}$ or $\mathrm{C}$. These are floras that have taken 
advantage of the instability of the belts and dominated ecological spaces locally unfavourable to elements of the contiguous domains (A, B and $\mathrm{C}$, or $\mathrm{B}, \mathrm{C}$ and $\mathrm{D}$, or even $\mathrm{A}, \mathrm{C}$ and $\mathrm{F}$ ), but favourable to certain specific floras, cocais (palm forests) and matas de cipó (vine forests).

No detailed research has been carried out yet in these belts. My own itineraries have rather been transects, but they permit me to present basic models of the natural organization of the transition and contact belts, of course of a very preliminary character.

1. Transition belts due to topographical and topoclimatic compartmentation (Central Bahia).

2. Complex belts (agreste type), in areas of sharp climatic fluctuations between subhumid and moderately sub-arid climates.

3. Transition due to sharp changes of topographical and pedological features (sublittoral zones of Sergipe and Paraíba).

4. Belts with subnuclei of buffer vegetation (palm forests of Maranhão, vine forests of Bahia).

5. Mosaic belts, controlled by soils, paleosols and inheritance of topographical position (plateau of Franca and northeastern São Paulo).

6. Transition between cerrados and dry forests, separated by broad belts of gallery forest (pre-Amazonian Maranhão, Pontal area of São Paulo).

7. Belts with mixtures of floras, or with orderly or semi-orderly coalescence of vegetation types (Pantanal of Mato Grosso, Paranaguá Plateau, Island of Marajó).

8. Belts of the inter- and subtropical littoral zones, with interference of marine, eolian, lacustrine and fluvial processes (littoral of Amapá, Lençóis Maranhenses, coast of Rio Grande do Norte, sandstone reef coasts, littoral of Sergipe and Bahia, Cabo FrioMacaé in Rio de Janeiro, Cananéia-Iguape in São Paulo, coastal plain and lagoons in Rio Grande do Sul).

Each of these regional models is characterized by a subtle combination of easy-tounderstand physiographical and ecological facts. It is harder, however, to carry out more detailed studies aimed at analyzing and appraising the elements that combine to give rise to the subregional landscape complexes. Such studies will demand multidisciplinary teams and a determined effort of complex physiographic cartography.

\section{THE EVOLUTION OF FLORAS FROM THE CRETACEOUS TO THE QUATERNARY IN BRAZIL}

I plead that it be permitted to a nonspecialist attempt to assemble the fragmentary documentation on the plant cover of Brazil since the Cretaceous; it is anyway mostly indirect evidence. I here add some new information to a previous review (AB'SÁBER, 1951) aimed at geomorphologists.

In my opinion a fundamental starting point is the presence of caliches and similar deposits in the Bauru Group and other Cretaceous formations. The Early Cretaceous was a time of large deserts (the Botucatu Desert); from then on there was an attenuation of the aridity. Judging from the contemporary sediments, a large part of the country had hot semi-arid and semi-humid climates, the general landscape being one of large shallow lakes filling inland detritic depressions, surrounded by semi-desertic areas of sub-continental size.

The presence of caliches in such disparate areas as the Triângulo Mineiro (southwesternmost Minas Gerais), Rubião Junior, São Paulo, and the northeastern chapadas (Apodí, Araripe), where lacustrine limestones occur, points to soils of pedocal type, formed under harsh, semi-arid conditions. At that time, the vegetation would have been of a sub-desertic type, in agreement with the soil types - in any case a type of vegetation very different from any presently known.

The post-Cretaceous uplift of the Brazilian plateau, and the attendant phenomena of circumdenudation that compartmented the great block extending from Rio Grande do Sul to the border of the Amazon basin, resulted in different landscapes, under climates much moister than the Cretaceous ones, and with exorheic drainages, frankly open to the sea. This new topography, more compartmented and with soils produced by moister climates, lasted for long periods of the Tertiary. I believe that from the Mid-Tertiary on, the prevailing soils were pedalfers. This was, in fact, the great global change in the evolution of the plateaus and inland landscapes of Brazil betweeen the Late Cretaceous and the Tertiary.

In the assembly of evidence about this 
strong ecological change, a distinctive part refers to small detritic basins in compartments of the Brazilian plateau, where certain types of sediments were preserved. During the Tertiary epeirogenic uplift, there was an extraordinary evacuation of detrital materials through the open drainage toward the River Plate and the continental platform, few inland sedimentation areas remaining free from erosion. Such are the basins of Taubaté, São Paulo, Curitiba, Rezende, Volta Redonda, Atibaia, Fonseca and Gandarela, as well as some isolated coastal basins in the northeast and in the south of the country (Ribeira, Alexandra, Pelotas). In the Northeast and in Amazonia there remain important detrital masses dating from the late Tertiary or the early Quaternary. The presence of huge clay strata in these beds shows that, before they were deposited, the area had soils resulting from chemical weathering in humid conditions, with thick regoliths, especially on crystalline rocks. Without this prior formation of clays, there would have been no matrix for the fine sediments of the basins. In fact, the removal of the altered clay beds would have been possible only during an aggressive phase of areolar erosion, concomitantly with eventual tectonic damming of certain plateau compartments, or with a new phase of basin formation, as in Amazonia.

There must have been a steady and intensive flow of fine sediments toward the River Plate and the continental platform, the only exceptions been those carried to the Amazon Basin, and those originating in the intermontane compartments of the Northeast and carried to the band now occupied by the detritic Barreiras Group. Identically, the sediments that remained nested in a few, but highly significant, plateau compartments of southeastern Brazil, document the alternation of humid and dry climates, with a general predominance of pedalfer soils.

It is important to note, based on such facts, that all the vegetation stocks closely related to the present inter- and subtropical vegetation (forests, cerrados, caatingas, araucaria and prairies) were elaborated after the Mid-Tertiary. During the Quaternary, such floras fluctuated in space, controlled by successive climatic changes, consequent upon the unstable climatology of the period.

There are suspicions that in some areas there may have been steppes or grasslands only slightly different from present ones. There is reason to believe, however, that the basic stocks were already shaped by the end of the Tertiary and persisted throughout the Quaternary in diversified and complex spatial arrangements. It is not yet possible, however, to map securely the evolution of the vegetation during these times; the information is still too fragmentary.

\section{MAMELONIZATION VS}

\section{PEDIMENTATION IN THE EVOLUTION OF THE RELIEF OF ATLANTIC TROPICAL BRAZIL}

Regional geomorphological research and studies of the changes of pace in the physiology of the landscape consequent upon Quaternary climatic fluctuations have clarified many questions related to the expansion and retreat of forests in Atlantic tropical Brazil.

André Cailleux and Jean TRICART (1957), based on evidence from Quaternary deposits and other geomorphological features, first established that intensive fluctuations between humid and dry climates occurred in Atlantic tropical Brazil during the Quaternary. On the other hand, the Northeast would have had more stable semi-arid climates, similar to the present one (TRICART 1958). I used to think differently (AB'SÁBER 1956) but now partially agree with Tricart. As for Central Brazil, I think that climatic fluctuations were more pronounced in the interplateau depressions that surrounded or penetrated the regional chapadões. The cerrado landscape should have been more or less stable in the higher areas, the changing climates (Sudanese-type) affecting instead regions such as the depression between the Espigão Mestre (E.n.: plateaus of northwest Minas Gerais and west Bahia) and the Brasilia Plateau, or the interplateau depressions of the Upper Araguaia and the Paraná Basin.

In the present work I shall confine myself to the question that I consider fundamental to the knowledge of paleoclimatic and paleoecologic fluctuations in the eastern and southeastern Atlantic facade of Brazil, i.e., the alternation of drier and moister climates and its phytogeographic implications.

In southeastern Brazil, as shown by several authors, there is a topography, regional in expression, constituted by an endless succession of rounded slopes (DEFFONTAINES 1959). It is the domain of the seas of hills, in my latest conception of this area from the viewpoint of regional morphoclimatic characterization (AB'SÁBER 1963, 
1966). The individual features have been called half oranges, turtle shells, rumps, elephant-back hills, round hills, mamelões (E.n.: rounded breastlike hills) and other terms related to their visual appearance. Technically, in terms of geometric characterization, they would be polyconvex slopes (LIBAULT 1971).

Geomorphological studies performed in southeastern Brazil, the core area of the seas of hills domain, have shown that, parallel to the development of rounded, predominantly gneissic and granite-gneissic slopes, there occurred a dissemination of humid tropical pedogenetic processes and a spread, via coalescence, of forests over mamelonizated slopes and the uneven interfluves of mountainous areas.

The word mamelonization is here used in the sense of an ensemble of physiographical processes sufficient to round off slopes of weathered crystalline rocks into polyconvex shapes, in parallel with the deepening of chemical weathering and the dendritification of the minor branches of the drainage. It is in fact a system of integrated evolution of the landscape, rapidly elaborated and long-lasting in the absence of intervening climatic changes toward savanna or even drier climates.

Pedimentation is here used in the sense of a process of restrictive lateral planation, occurring predominantly on piedmont or intermontane areas, under the influence of subtropical climatic fluctuations. It should be noted that these pedimentation processes occur in subtropical and even in extra-tropical areas, by convergence. Here I shall deal with pedimentation within the southeastern Brazil model.

Intertropical pedimentation and mamelonization are opposing processes. In areas subject to mamelonization, with deeply decomposed rocks stabilized by the protection of tropical forests, only radical, sharp climatic changes can launch aggressive phases of generalized erosion, at the end of which the region will have suffered limited lateral planation by pedimentation. It is a process of formation of erosional ramps, lateral to the axes of intermontane depressions, where semi-aridity may have set in early, or, still, of this same type of ramp at the foot of scarps or mountains whose lower slopes face semi-arid littoral or sublittoral belts. At any rate, pedimentation will only occur by removal of the regolith of the rounded hills in specific topographic situations, involving the presence of low hills embedded in higher relief, or asymmetric areas at the foot of humid tropical scarps. Such conditions were present during the whole Quaternary in the middle valley of the Paraíba, on almost all tropical scarps of Atlantic Brazil, and in many other intermontane and interplateau compartments of inner Brazil.

Geomorphological observations made during the last 25 years permit me to assert that intertropical pedimentation can only occur in its fullness during the transition from a phase of landscape shaping by mamelonization to a phase of aggressive regional erosion, yet only when restricted to intermontane or piedmont compartments.

Pedimentation ramps would result from sharp changes in the physiology of the landscape. After a long phase of mamelonization under general forest cover, the change to a drier climate would result in aggressive erosion of the hills with initial loss of forest cover and the ensuing appearance of multiple ravines, widespread removal of polyconvex slopes in the intermontane compartments, and transport of detrital materials away from the main area of pedimentation. This description is enough to characterize the process of mamelonization in the terminology ERHART (1955) as typical of biostasy, occurring in humid phases, and pedimentation, taking place during a phase of instability and change, as a typical processes of rhexistasy.

During periods of mamelonization, tropical forests reached their maximum extent, by coalescence of refuges and by an "oil stain" type of spread. On the contrary, pedimentation phases, corresponding to dry intermontane and/or littoral climates, were phases of retraction of the plant cover into isolated remains, such as the present "brejos" of northeastern Brazil, isolated areas of humidity located on slopes, mountain tops, foothills, along creeks, and around springs. Consequently, and given the regional network of clearly compartmented semi-aridity, this is the phase that prepares the landscape for the penetration of semi-arid vegetation into the drier sectors of the pedimented and pediplaned areas (inner interplateąu and intermontane compartments) and/or semi-arid coastal areas.

\section{THE FINAL STAGES OF MAMELONIZATION}

It is possible to say that the 
present polyconvex slopes are the result of intensive chemical and biogenic activity antecedent to the formation of the paleopavements. A long period of chemical weathering, tropical pedogenesis and polyconvex shaping was in a certain moment interrupted by a sporadic dry phase, which caused partial retraction of the forest cover and the appearance of slopes with stony soils, upon which there must have existed a landscape of caatingas or sparse cerrados (more probably the former). When the critical period of the phase of geologically short duration was over, the interrupted process was resumed: chemical weathering, tropical pedogenesis, return of unbroken forest cover and strong colluvial activity, as evidenced by the deposits that overlie the stone lines.

It is important to note that the last sporadic dry episode of the Quaternary (the stone line phase) produced a laminar stripping of soils, resulting in detritic pavements of diversified structure and thickness. There was not enough time, however, for a new phase of pedimentation, such as had repeatedly occurred in the Pleistocene. On the contrary, resumption of mechanical morphogenesis in an environment of scrubby and sparse vegetation permitted only the formation of discontinuous stony soils, some made up of fragments of quartz dykes, others enriched with Quaternary river gravels reworked and spread out as detritic pavements (AB'SÁBER 1962, 1969).

One is led to believe that during this sporadic, relatively modern dry episode (Pleistocene-Holocene boundary, or even Holocene or sub-recent), retraction of the forest was discontinuous and incomplete. Otherwise it was in most places a short phase, since there was a return to humid tropical conditions with progressive emphasis on colluviation, parallel to the reactivation of chemical weathering, sufficient to bury the stony soils. The forests could then leave their sizable refuges, and advance over colluvial soils, helping the maturation of pedogenetic processes and contributing to the reconstruction of the humid tropical landscape.

The buried stone lines remained as witnesses of this last dry phase that affected areas of southeastern Brazil that are nowadays extensively humid. This perception is due to CAILLEUX \& TRICART (1957). I wish to underline that the most recent stone lines coincide with the coarser fluvial deposits on basal or intermediate levels of the floodplains, especially in the case of middle- and small-sized rivers. The large floodplains, such as those of the Tietê and Pinheiros, or middle Paraíba, may contain older deposits in their lower levels of the alluvial sequence, going back perhaps to the Late Pleistocene.

Knowledge of the superficial structure of the landscape of the domain of the seas of hills in southeastern Brazil is relevant to geotechnical and conservation matters. It is intuitive that widespread removal of the forest, and the subjection of the landscape to an uncontrollable predatory process will result in an immediate disequilibrium, with unpredictable consequences. A sort of anthropic rhexistasy (AB'SÁBER 1965) is created. The originator of the biorhexistasy theory (ERHART, 1955) introduced the idea that the main rhexistasy would be anthropic; I cannot agree. There is, however, a certain rhexistasy associated with anthropic action, and the domain of the seas of hills, especially along the Middle Paraíba, constitutes the most striking example of such a disequilibrium (AB'SÁBER 1965). The stone lines buried under cover deposits are the only elements capable of maintaining a consistent superficial structure and a relative equilibrium in a landscape modified by man. Any injury reaching below the irregular horizon of the stone lines may result in the savage, and eventually multiple gullying (boçorocas).

A word to prehistorians: in the case of a country with a relatively recent prehistoric population, it is indispensable to know the reference planes in the stratigraphy of the Upper Quaternary. It is always necessary to refer finds to the cover deposits and to the stone lines. It seems that the cover deposits, as well as the basal deposits of some floodplains, are the only ones that played a role as correlative deposits of the possible landscapes occupied by prehistoric man in Brazil. It is even possible to say that most groups of primitive Brazilians lived and moved in landscapes posterior to the last dry episode. However, based on some datings, of modern sediments and of archeological industry, it is possible to infer that some archaic groups may have lived at the time of the stone lines or of some pene-contemporary sand banks or sandbodies. Except in the case of burials cutting through the stone lines, it will be possible to date relatively any artifactual or skeletal materials found among the stone line gravels or rock fragments; the age will be a few thousand years. Of course, only radiometric dating will afford more precise data. 


\section{FINAL CONSIDERATIONS}

From the study of the great landscape domains in the country, it is possible to establish a series of conclusions relative to the natural organization of spaces in Brazil. Even better, it is possible to obtain a better understanding of the spatial distribution of regional landscape patterns and models both in core areas as well as in the transition and contact belts.

One soon perceives that the landscape mosaic is markedly original when compared with other sectors of the intertropical belt on Earth. All domains possess significantly homogeneous polygonal core areas. On the contrary, the anastomosed belts that surround the cores are discontinuous, showing diversified physiographic variations and combinations in accordance with their positioning between two or three domains. It is therefore difficult to recognize patterns within these belts, making it necessary to establish models of relative validity.

In the interior of the core areas there are regional landscape patterns always related to a same family of regional ecological environments. While the intertropical domains have areas between 750,000 (semi-arid domain) and 3 million $\mathrm{km}^{2}$ (forested lowlands of Amazonia), patterns within the cores vary in area, due to peculiarities of topography, lithology, sub-regional climates, and soils; they may measure from a few thousand to hundreds of thousands of square kilometers. In all cases the differences are subtle, visible only to capable specialists.

Besides these moderate differences in landscape patterns, there is stronger cause for contrasts within the cores: the apparently anomalous landscapes of the enclaves. These are practically always small, measuring from a few hundred to a few thousand sq $\mathrm{km}$. In spite of their small aggregate area, at most $5 \%$ of the total area of each domain, they significantly enrich the landscape.

The magnitude of the landscape patterns in each domain is not uncommonly of subregional dimensions. In contrast, enclaves are more restricted in size, usually comprising small regional landscapes of a few hundred (or less) to several thousand square kilometers.

Another level of variation concerns the physiographic variations and combinations of the transition and contact belts. These do not show polygonal arrangement like that of the cores.
Furthermore, although simplified cartography may suggest that they are broad corridors, each sector of each arm of these elongated belts presents a peculiar, almost exclusive combination of physiographic facts. Since it is not feasible to characterize all the features of the transition and contact belts, we shall describe some of the principal models.

They show alternation, interference, mixture or fusion of schemes belonging to more than one neighboring domain. They may include some landscapes proper to the domains, mixed with transitional ones: this is what I call buffer landscapes. One additional model is a sub-belt or sub-polygon, in which an individualized botanical landscape can establish itself, different from everything that exists in the cores (palm forests, vine forest).

It should be remembered that the total richness of the inter- and subtropical landscapes of Brazil is a consequence of these structures we have just considered. Subtle variations, of little spatial import, are evidenced by regional patterns of landscapes of each domain. Strong contrasts occur inside the cores due to the presence of enclaves; extraordinary and frequent variations, due to the combination of interfering physiographic factors, characterize the transition and contact belts. The sum constitutes a much richer conjuncture than it was possible to guess a few years ago.

Since the present landscapes are the heritage of a complex and continuous evolution related to Quaternary vicissitudes of the intertropical world, it is indispensable to establish the position of such landscape schemes in the face of biostasic or rhexistasic conditions. I believe that almost all Brazilian landscapes pertain to biostasic conditions, even, at least in part, the natural landscapes of the semi-arid Northeast. It is also certain that Man, irregularly but in places extensively, brought about scattered effects of anthropic rhexistasy. It is indispensable to try to understand that the present picture represents a scheme elaborated during a biostasic phase, starting from the very different landscapes of the dry phases of the Quaternary. I believe that at certain times there was widespread semi-aridity, in the style of present northeastern landscapes, albeit under probably more active rhexistasic dynamics. Such a penetration of semi-aridity throughout the intermontane compartments resulted in several resumptions of pedimentation. 
Again, each phase of pediment formation alternated with epochs of much or little mamelonization of the topography and chemical weathering of the rocks.

Coastal regions, littoral or sub-littoral, were subject not only to marginal epeirogenesis of the Brazilian Plateau, fault tectonics and continental flexure, but also to another set of variations, associated with the intrusion, from south to north, of a tongue of dry climates along the Atlantic facade. I believe that in times of low mean sea level (due to glacio-eustatic control) the cold currents of the southwestern Atlantic reached farther north than they do now on the coast of Rio Grande do Sul, possibly causing upwelling of the present Cabo Frio type north of Espirito Santo. This would cause extensive aridity and cooler winters.

The summation of the semi-aridity of the northeastern intermontane type with that resulting from the coastal intrusion from the south created conditions for the prevalence of semi-arid, and perhaps partially sub-humid climates, in large areas of Brazil. There was also, and it is important to note, a zonation of the dry climates, and resultant reduced presence of all landscape stocks presently known in the country. It is thought that the dry-epoch landscapes had azonal schemes or, at least, that most of them had little zonal expression. However, conditions do not yet exist to attempt a valid cartography of any of the predominantly dry phases of the Quaternary. I prefer to characterize the two great models of penetration vs relative generalization of dry climates, rather than present even a tentative map of the mosaic of environments and landscapes of our country during any specific dry phase.

\section{BIBLIOGRAPHY}

\section{I - Specific works}

AB'SÁBER, A.N. 1951. Sucessão de quadros paleogeográficos no Brasil, do Triássico ao Quaternárío. Anuário da Faculdade de Filosofia Sedes Sapientiae, São Paulo: Universidade Católica de São Paulo, 1950-51, p. 61-69.

- 1958. Conhecimentos sobre as flutuaçães climáticas do Quaternário no Brasil. Notícia Geomorfológica, 1(1): 24-30.

- 1959. Pavimentos detríticos atuais e subatuais das caatingas brasileiras. Notícia
Geomorfológica, 2 (4): 48-49.

— 1962. Revisão dos conhecimentos sobre o horizonte subsuperficial de cascalhos inhumados do Brasil Oriental. Curitiba: Instituto de Geologia da Universidade do Paraná, 31p. (Boletim da Universidade do Paraná, Geografia Física, 2).

— 1963. Contribuição à geomorfofogia da área dos cerrados. In: Simpósio sobre o Cerrado, São Paulo, Editora da USP, p. 117-124.

— 1965. Da participação das depressões periféricas e superfícies aplainadas na compartímentação do Planalto Brasileiro. Faculdade de Filosofia Ciências é Letras, Universidade de São Paulo, São Paulo, Tese de Livre-Docência.

— 1966a. O domínio morfoclimático dos mares de morros no Brasil. São Paulo: Instituto de Geografia, Universidade de São Paulo, 9 p. (Geomorfologia, 2).

— 1966b. O domínio morfoclimático amazônico. São Paulo: Instituto de Geografia, Universidade de São Paulo, 11p. (Geomorfologia, 1).

— 1967a. Problemas geomorfológicos da Amazônia Brasileira. Simpósio sobre a Biota Amazônica, Atas (Geociências), 1: 35-67.

— 1967b. Domínios morfoclímáticos e províncias fitogéográficas do Brasil. Orientação, (3): $45-48$.

— 1968. As boçorocas de Franca. Revista da Faculdade de Filosofia de Franca 1 (2): 521.

-1969a. O Quaternário na Bacia de Taubaté: estado atual dos conhecimentos. São Paulo: Instituto de Geografia, Universidade de São Paulo, 22 p. (Geomorfologia, 7).

— 1969b. O Quaternárío na Bacia de São Paulo: estado atual dos conhecimentos. São Paulo: Instituto de Geografia, Universidade de São Paulo, 15 p. (Geomorfologia, 8).

1969c. Pedimentos e bacias detríticas pleistocênicas em São Paulo. São Paulo: Instituto de Geografia, Universidade de São Paulo, 12 p. (Geomorfologia, 9).

— 1969d. Uma revisão do Quaternário Paulista: do presente para o passado. Revista Brasileira de Geografia, 31(4): 1-33.

- 1970a. As ilhas de cerrados das bacias de Taubaté, São Paulo e Atibaia. São Paulo: 
Instituto de Geografia, Universidade de São Paulo, p. 20-24 (Cadernos de Ciências da Terra, 6).

- 1970b. O mosaico primário de matas e cerrados do Planalto Paulistano.São Paulo: Instituto de Geografia, Universidade de São Paulo, p. 24-29 (Cadernos de Ciências da Terra, 6).

— 1970c. Os lajedos da Serra de São Francisco: um exemplo de aridez rochosa no Estado de São Paulo. São Paulo: Instituto de Geografia, Universidade de São Paulo, p. 2932 (Cadernos de Ciências da Terra, 6).

— 1970d. Províncias geológicas e domínios morfoclimáticos no Brasil. São Paulo: Instituto de Geografia, Universidade de São Paulo, 26 p. (Geomorfologia, 20).

ANDRADE, G. O. 1958 - O relevo da zona pioneira do Espírito Santo e da Região Contestada. Recife: Diretório Acadêmico da Faculdade de Filosofia, Universidade do Recife, Coleção Filosofia, Ciências e Letras (3).

— 1964. Armazenamento d'água em pedimentos detríticos. Arquivos do Instituto de Ciências da Terra, 2: 37-42.

-; BIGARELLA, J.J. 1964. Considerações sobre a estratigrafia e sedimentologia do Grupo Barreiras, Região de Recife. In: AGB, ASSEMBLÉIA GERAL, 19, Poços de Caldas.

---; ---; LINS, R.C.1963. Contribuição à Geomorfologia e Paleoclimatologia do Rio Grande do Sul e do Uruguai. Boletim Paranaense de Geografia, (8 /9): 123-131.

--); LINS, R.C. 1963 Introdução à morfoclimatologia do Nordeste do Brasil. In: SBG, CONGRESSO BRASILEIRO DE GEOLOGIA, 17, Recife.

AZEVEDO, L.G. 1963. Tipos de vegetação do Sul de Minas e Campos da Mantiqueira (Brasil). Anais Academia Brasileira de Ciências, 34 (2): $225-254$.

— 1965. Contribuição à delimitação dos tipos de vegetação do Estado de Sao Paulo. Região de Campos do Jordão. Arquivos de Botânica do Estado de São Paulo, 4 (1): 11-21.

— 1966. Tipos Eco-físionômicos da Vegetação da Região de Januário. Anais Academia
Brasileira de Ciencias, 38: 38-57

BIGARELLA, J.J. 1964. Variações climáticas no Quaternário e suas implicações no revestimento florístico do Paraná. Boletim Paranaense de Geografia (10/15): 211-232.

- 1965. Subsídios para o estudo das variações do nível oceânico no Quaternário Brasileiro. Anais da Academia Brasileira de Ciências, 37 (Suplemento): 263-278.

-; ANDRADE, G.O. 1965. Contribution to the study of the Brazilian Quaternary. In: International Studies on the Quaternary. Geological Society of America, Special Paper (84): 433-451.

MOUSINHO, M.R. 1965a. Considerações a respeito dos terraços fluviais, rampas de colúvio e várzeas. Boletim Paranaense de Geografia, (16/17): 153-198.

-; — 1965b. Contribuição ao estudo da Formação Pariquera-Açu (Estado de São Pau1o). Boletim Paranaense de Geografia, (16/ 17): $17-41$.

—; SILVA, J.X. 1965a. Considerações a respeito da evolução das vertentes. Boletim Paranaense de Geografia, (16/17):85-116.

- - - ;- 1965b. Pediplanos, pedimentos e seus depósitos correlativos no Brasil. Boletim Paranaense de Geografia, (16/17):117-152.

- - - ;- 1965c. - Processes and environments of the Brazilian Quaternary. Prepared for the VII INQUA CONGRESS, Fairbanks, Alaska, Imprensa Universitária do Paraná, Curitiba, 69 p.

—; SALAMUNI, R.; AB'SÁBER, A.N. 1961. Origem e ambiente de deposiçío de Bacia de Curítiba. Boletim Paranaense de Geografia, (4/5): 71-81.

BENNEMA, J.; CAMARGO, M.; WRIGHT, A.C.S. 1962. Regional contrast in South American soíl formation, in relation to soil classification and soil fertility. In: INTERNATIONAL SOIL CONFERENCE, New Zeland.

BIROT, P. 1957. Esquisse morphologique de la région litorale de l'État de Río de Janeiro. Annales de Géographie, (353): 80-91.

BRANNER, J.C. 1911. Aggraded limestone plains of the interior of Bahia and clímatic changes suggested by them. - Geological Society of America Bulletin, 22: 187-206. 
CAILLEUX, A. 1957. Observations sur la ligne de cailloux à la base des sols jaunes. Zeitschrift für Geomorphologie, 1: 312.

— 1966. Os depósitos detritícos, a linha de cascalhos enterrados e os cupins. Notícia Geomorfológica, 6 (12): 43 -49.

-_;RICART,J.1957.

Zones phytogéographiques et morphoclimatiques au Quaternaire au Brésil. C. R. Soc. de Biogéographie, (293): 7-13 [Tradução: Notícia Geomorfológica 2(4): 12-17].

CHRISTOFOLETTI, A. 1965a. Vestígios paleoclimáticos na borda ocidental do Planalto Atlântico Paulista. In: CONGRESSO BRASILEIRO DE GEÓGRAFOS, 2 , Rio de Janeiro, Resumo de Teses e Comunicações.

- 1965b. Nota sobre a cascalheira encontrada na rodovia entre Campinas e Viracopos. Ciência e Cultura 17(2): 126.

— 1966. Considerações a propósito da Geografia Físíca Cerrados. Notícia Geomorfológica, 6 (11): 5-32.

— 1968. O fenômeno morfogenético no município de Campinas. Notícia Geomorfológica, 8(16):1-97.

—; PENTEADO, M.M. 1970. Cronologia relativa do Quaternário na depressão periférica paulista. Notícia Geomorfológica, 10 (19): 35-46.

COUTINHO, J.M.V. 1955. Geologia e petrologia da região de Piraí do Sul. Boletim da Sociedade Brasileira de Geologia, (1): 49-65.

DAMUTH, J.E.; FAIRBRIDGE, R.W. 1970. Equatorial Atlantic deep-sea arkosic sands and ice-age aridity in tropical South America. Bulletin Geological Society of America, 81: 189-206.

DELANEY, P.J.V. 1960. A planície costeira e o sistema lagunar do Rio Grande do Sul. Notícia Geomorfológica, 3 (6): 5-12.

— 1962. Fisiografia e geologia de superfície do Rio Grande do Sul. Porto Alegre: Escola de Geologia, Universidade do Rio Grande do Sul, Publicação Especial (6): 1-105.

DENEVAN, W.M. 1963. Physical Geography of the Planalto Central. In: Survey of the agriculture of the Central Plateau of Brazil. Mimeografado, p. 1-37.

DOMINGUES, A.J.P. 1967. Classificação das re- giões morfoclimáticas brasileiras. In: Elementos de Geomorfologia Climática, Curso de Férias para Professores, C.N.G.IBGE, Rio de Janeiro, p. 72.

DRESCH, J. 1957a. Les problèmes morphologiques du Nord'Est brésilien. Bulletin de l'Association des Géographes Français, (263/264): 48-59 [Tradução: Notícia Geomorfológica, 1 (2):13-21].

— 1957b. Le Nord'Est. Annales de Géographie, 66(353): 71-74.

EMPERAIRE, J.; LAMING, A. 1956. Les sambaquis de la Côte Méridionale du Brésil. (campagne des fouilles 1954-1956). Paris: Societé des Américanistes, Journal, N. Sér., 45: 5-103.

FEUR, R. 1956. An exploratory investigation of the soils and the agricultural potencial of soils of the future federal district in the central plateau of Brazil. Cornell University, Ithaca, Tese.

FOX, P.P. 1953. Geology of the Santa Cecilia Tunnel. Boletim da Sociedade Brasileira de Geologia, 2(1): 17-23.

HAFFER, J.1969. Speciation in Amazonian forest birds. Science, 165 (3889): 131-137.

HUECK, K. 1966. Die Wälder Sudamerikas. Ökologie, Zusammensetzung und Wirtschaftliche Bedeutung. Gustav Fischer Verlag, Stutgart. Tradução: H. Reichardt, As florestas da América do Sul, Editoras Universidade de Brasília e Polígono S.A., São Paulo, 1972.

HURT, W.R. 1964. Recent radiocarbon dates for Central and Southern Brazil. American Antiquity, 30 (1): 25-33.

LIBAULT, A. 1971. Pão de açucar e mar de morros. Boletim Paulista de Geografia, (46): 3-28.

LIMA, D.G. 1964. Contribuição à dinâmica da flora do Brasil. Recife: Instituto de Ciências da Terra, Universidade do Recife, p. 40 - 46 (Arquivos, 2).

LINS, R.C.; ANDRADE, G.O. 1963. Diferentes combinações do meio natural da zona da mata nordestina. Introdução ao estudo dos fatores naturais na agro-índústria do açúcar. Recife: Cadernos Faculdade de Filosofia de Pernambuco, Departamento de Geografia, Serie VI-6. 
MAACK, R. 1948. Notas preliminares sobre clima, solos e vegetação do Estado do Paraná. Arquivos de Biologia e Tecnologia, 2: $99-$ 200.

— 1950. Mapa fitogeográfico do Estado do Paraná. Escala: 1.750.000, Curitiba.

— 1961. Modificações da paisagem natural pela colonização e suas consequências no Norte do Paraná. Boletim Paranaense de Geografia, (2/3): 29-48.

— 1962. Geologia e Geografia Física da Bacia Hidrográfica do rio das Contas no Estado da Bahia. Curitiba: Universidade do Paraná, (Boletim Geografia Física, 5).

MARTONNE, E. De. 1940. Problèmes morphologiques du Brésil tropical atlantique. Annales de Géographie, 49 (277): 1-27 (e) (278/279): 106-129.

MORRIS, R.H. 1961. Geologia Geral das quadrículas Gravataí e Rolante, Rio Grande do Sul. Porto Alegre: Escola de Geologia da Universidade do Rio Grande do Sul (Publicação Especial, 5).

MORTENSEN, H. 1957. Über eine Oberflanformen nordlich Rio de Janeiro, in der Serra do Mar und in Itatiaia-Gebirge. Zeitschrift für Geomorphologie, 1(3): 296302.

PENTEADO, M.M. 1966. Condições geomorfológicas do aprovisionamento da água, na área de Rio Claro. Notícia Geomorfológica, 6 (12): 15-42.

— 1967. A bacia de sedimentação de Rio Claro. In: AGB, ASSEMBLÉIA GERAL, Franca.

— 1968. Geomorfologia do setor centro-ocidental da Depressão Períférica Paulista. Instituto de Geografia, Universidade de São Paulo (série Teses e Monografias, 22) 86 p. Tese de Doutoramento.

— 1969. Novas informações a respeito dos pavimentos detríticos (stone lines). Notícia Geomorfológica, 9 (17): 15-41.

- 1970. Características dos pedimentos nas regiões quentes e úmidas. Notícia Geomorfológica, 10 (19): 3-16.

PIMIENTA, J. 1956 - Modifications climatiques et sudsidense récent affectant le glacis sud du basin de l'Amazone (Rio Tocantins). C. R. Académie Sciences Paris, 246 (15):
2268-2271.

RAYNAL, R. 1957. Les formations des versants et l'évolution climatique dans la Serra da Mantiqueira. Zeitschrift für Geomorphologie, 1(3): 279-289 [Tradução: Notícia Geomorfológica 5(9/10):4347].

RUELLAN, F. 1953. O papel das enxurradas no modelado do relevo brasileiro. Boletim Paulista de Geografia, (13): 5-18 e (14): 3-25.

SAKAMOTO, T. 1957. Trabalhos sedimentológicos e geomorfológicos pedogenéticos referentes à Amazônia. Belém: Missão FAO-UNESCO junto à SPVEA (Mimeografado).

TAKEUCHI, M. 1960. The structure of the Amazonian vegetation. I. Savanna in northern Amazon. Tokyo: Journal Faculty Sciences, University of Tokyo, 3 (7): 523 533.

TRICART, J. 1957. Alguns problemas geomorfológicos da Bahia. Boletim Carioca de Geografia, 10 (3/4): 17-26.

1958. Division morphoclimatique du Brésil atlantique central. Révue de Géomorphologie Dynamique, 9 (1): 122.[Tradução: Boletim Paulista de Geografia, (31): 3-44.]

— 1959a. As zonas morfoclimáticas do Nordeste Brasileiro. Salvador: Publicação da Universidade da Bahia.

— 1959b. Problèmes morfologiques du líttoral oriental du Brésil. Cáhiers Oceanographiques, 11 (5).

— 1959c. Caracteres da evolução do litoral do Brasil oriental. In: COLÓQUIO INTERNACIONAL DE ESTUDOS LUSO-BRASILEIROS, 4, Salvador, Resumo das Comunicações, p. 77-79.

— 1961. Le modélé du Quadrilátero Ferrífero au Sud de Belo Horizonte. Annales de Géographie, 379: 255-272.

_-; CAILLEUX, A. 1965. Le modele des régions chaudes. Forets et savanes. In:Traíté de Geomorphologie, Paris, SEDES, tome V.

—; SILVA, T.C. 1958. Aspectos da sedimentação da Bacia de Taubaté (São Paulo - Brasil). Notícia Geomorfológica, 1(1):6-13. -1968. Estudos de geomorfología da Bahia 
e Sergipe. Fundação para o Desenvolvimento da Ciência na Bahia, Salvador.

VAN DER HAMMEN, T. 1963. Problems of Quaternary botany in the tropics (with special reference to South America). - Ber. Geobot. Inst. ETH, Zürich, p. 34-62.

VANZOLINI, P.E. 1970.Zoologia Sistemática, Geografia e a Origem das Espécies. São Paulo: Instituto de Geografia, Universidade de São Paulo (Série Teses e Monografias, 3).

—; AB'SÁBER, A.N. 1968. Divergence rate in South America lizards of genus Liolaemus (Sauria, Iguanidáe). São Paulo: Museu de Zoologia, Universidade de São Paulo, pp. 205-208 (Papéis Avulsos Zoologia, 21).

-; WILLIAMS, E.E. 1970. South American anoles: the geographic differentiation and evolution of the Anolís chryosolepis species group (Sauria, Iguanidae). São Paulo: Museu de Zoologia, Universidade de São Paulo, (Arquivos de Zoologia 19).

\section{General works}

AUBREVILLE, A. 1949. Climats et desertifícation de l'Afrique tropicale. Soc. Edit. Géogr. Marit. Colon., Paris.

BAKKER, J.P. 1957. Quelques aspects du problème des sediments corrélatifs en climat tropical humide. Zeitschrift für Geomorphologie (1): 3-43.

BAULIG, H. 1956. Pénéplains et pédiplains. Bulletin Societé Belge d'Études Géographiques, 25(1): 25-58.

BERNARD, E.A. 1962. Interprétation astronomique des pluviaux et interpluviaux du Quaternaire africain. In: CONGRÉS PANAFRICAIN DE PRÉHISTOIRE, 4, Harvard, Actes, p. 67-96.

BERTRAND, G. 1968. Paysage et géographie globale. Esquisse méthodologique. Revue Géographique des Pyrenées et du SudOuest, 39 (3): 249-272.

BIROT, P. 1949a. Essai sur quelques problèmes de morphologie générale. Lisboa: Centro de Estudos Geográficos.

1949b. Sur le problème de l'origine des pédiments. In: CONGRÉS INTERNATIONAL DE GÉOGRAPHIE, Lisboa, C. R. 2: 9- 18.
1955. Les méthodes de la morphologie. Presses Universitaires de France, Paris.

1959. Géographie Physique Générale de la zone intertropicale (a l'exclusion des deserts). C.D.U., Paris.

; DRESCH, J. 1966. Pédiments et glacis dans I'Ouest des États Unis. Annales de Géographie, (411): 513-552.

BRYAN, K. 1935. The formation of pediments. In: INTERNATIONAL GEOLOGIAL CONGRESS, 16, 1933, Report 2: 765-775.

CAILLEUX, A. 1956. La era cuaternaria. Problemas y metodos de estudos. C.S.I.C., Barcelona.

; TRICART, J. 1956. Le problème de la classification des faits géomorphologíques. Annales de Géographie, 65 (349): 162 186.

DAVIES, 0. 1956. African pleistocene pluvials and european glaciations. Nature, 178 (4536): 757-758.

DRESCH, J. 1957. Pédiments et glacis d'érosion, pédiplains et inselbergs. L'Information Géographique, 21, (5): 183-186.

1959. Remarques sur les surfaces d'aplanissements et reliefs résiduels en Afrique Tropicale. In: CONGRÉS INTERNATIONAL DE GÉOGRAPHIE, 17, Rio de Janeiro, C. R. 2: 213-219.

1963. Geomorfologia dos escudos intertropicais. São Paulo: Conferência na Faculdade de Filosofia Ciências e Letras, Universidade de São Paulo, agosto de 1963 1966. Les paysages tropicaux humides. In: Géographie Génerale, Encyclopédie de la Pléiade, Eds. Gallimard, Paris, 20: 609711.

ERHART, H. 1956. La théorie bio-résistasique et les problèmes biogéographiques et paléobiologiques. C. R. Soc. de Biogéographie, p. 45-53. [Tradução: Notícia Geomorfológica, 6 (11): 51-58, 1966].

1958. La génèse des sols en tant que phénomène géologique. Masson e Cie. Eds., Paris, 174 p.

1966. Bio-résistasie, biostasies évolutives, hétérostasie. Importance de ces notions en geologie minière exogène. Paris: l'Academie de Sciences, C. R. des Séances, 
263, ser. D, (16):1048-51.

GARNER, H.F. 1966. Derangement of the Rio Caroni, Venezuela. Révue de Géomorphologie Dynamique, 16(12): 5483.

GUIÑAZU, J.R. 1928. Algunas observaciones sobre geomorfologia, suelos y clima de Rio de Janeiro, San Pablo y sus zonas adjacentes (Brasil). Buenos Ayres: Anales Sociedad Argentina de Estudios Geográficos GAEA, 3 (1): 259-290.

HAMELIN, L. E. 1968. A geomorfologia e suas relações com a geografia global e a geografia total. Boletim Geográfico, (204): 27 41.

HORBERG, L. 1952. Interrelation of geomorphology, glacial geology and Pleistocene geology. Journal of Geology, 60: 187-190.

MARKOV, K.K. 1956. Origine des paysages géographiques contemporains. In: Éssais de Géographie, Recueil des articles pour le XVIII Congrès International de Géographie (Rio de Janeiro). MoscouLeningrad, Edition de I'Academie des Sciences de I'URSS, p. 42-53.

MOREAU, R.E. 1966. The bird faunas of Africa and its islands. Academic Press, NewYork - London.

SCHNELL, R. 1961. Le problème des homologies phytogéographiques entre l'Afrique et l'Amérique tropicale. Memoires du Museum National d'Histoire Naturelle. N.S. Botan. 11 (2): 137-241.

STEVENS, P.R.; WALKER, T.W. 1970. The chronosequence concept and soil formation. Quarterly Review of Biology, 45(4): 333-350.

TRICART, J. 1956. Tentative de corrélation des périodes pluviales africaines et des périodes glaciaíres. Societé Géologique de
France, C. R. Somm., p. 164-167.

— 1958a. Notas sobre as variações quaternárias do nível marinho. Boletim Paulista de Geografia, (28): 3-13.

— 1958b. Observations sur le façonnement des rapides rivières intertropicales. Paris: Commission des travaux historiques et scientifiques, Impr. Nationale (Bulletin de la Sect. de Géogr.).

-_ 1959. Informações para a interpretação paleogeográfica dos cascalheiros. Notícia Geomorfológica, 2 (4): 1 - 11.

— 1961. Les caractéristiques fondamentales des systèmes morphogénétíques des pays tropicaux humides. L'Information Géographique, 25 (4): 155-169.

— 1963. Oscilations et modifications de caractère de la zone aride en Afrique et en Amérique Latine lors des périodes glaciaires des hautes latitudes. UNESCO e Organisation Meteorologique Mondiale, COLLOQUE DE ROME, Actes, p. 415-419.

TROLL, C. 1960. Die tropischen graslander unter dem Eímflus von klima, Boden und Wasser. In: CONGRESSO INTERNATIONALDE GEOGRAFIA, 18, Rio de Janeiro, C. R. 1: 302-307.

VAN DER HAMMEN, T.; GONZALES, E. 1964. A pollen diagram from the Quaternary of the Sabana de Bogotá (Colombía) and its significance for the geology of northern Andes. Geologie en Mijnbouw, 39: 737746.

VOGT, J.; VINCENT, P.L. 1966. Terrains d'altération et de recouvrement en zone intertropicale. Paris: Bureau de Recherches Géologiques et Minières, p. 2-111 (Bulletin 4).

WILHELMY, H. 1958. Klimamorphologie der massengesteine. - Georg. Westerman Verlag, Brauschweig.

Endereço do autor:

Aziz Nacib Ab'Sáber - Instituto de Estudos Avançados - USP, Edifício da Antiga Reitoria, Av. Prof. Luciano Gualberto, Travessa J, 374, Térreo, Cidade Universitária, 05508-900 São Paulo, SP, Brasil. 